\title{
Article/Artigo
}

\section{Epidemiological profile of meningococcal disease in the State of Minas Gerais and in the Central, North, and Triângulo Mineiro regions, Brazil, during 2000-2009}

\author{
Perfil epidemiológico da doença meningocócica, no Estado de Minas Gerais e nas regiões \\ Centro, Norte e Triângulo Mineiro, Brasil, de 2000 a 2009
}

\author{
Karynne Alves do Nascimento ${ }^{1}$, Sybelle de Souza Castro Miranzi ${ }^{2}$ and Lúcia Marina Scatena ${ }^{2}$
}

\begin{abstract}
Introduction: Infection by Neisseria meningitidis, termed as meningococcal disease, can cause meningococcal meningitis and septicemia with or without meningitis. Meningococcal disease is endemic in Brazil and has a high potential to cause large-scale epidemics; therefore, it requires the immediate notification of cases to the Information System for Notifiable Diseases (SINAN) in Brazil. The aim of this study was to describe an epidemiological profile using data from notified and confirmed cases in the State of Minas Gerais, Brazil, from January 2000 to December 2009, obtained from the investigation records of individuals with meningitis registered with SINAN. Methods: This was a retrospective, population-based study. Descriptive analysis of the data was made using the simple and relative frequencies of the categorical variables in the investigation records. Results: There were 1,688 confirmed patients in Minas Gerais of which $45.5 \%$ lived in the Central, North, and Triângulo Mineiro regions. The highest frequencies of cases were in the 1-4-years age group (26.3\%), males $(54.7 \%)$, caucasian $(36.4 \%)$, and lived in an urban area $(80 \%)$. In the patients with specified education, $650(60.9 \%)$ patients had secondary education. Serogrouping of meningococci had been performed in $500(29.6 \%)$ patients by age and gender; $285(57 \%)$ belonged to serogroup C, 67 (13.4\%) were in the 1-to 4-years age group, and 168 (33.6\%) were male. Conclusions: The epidemiological profiles of patients in the Central, North, and Triangulo Mineiro regions were not significantly different from the profile of patients in Minas Gerais. Keywords: Meningococcal meningitis. Epidemiology. Epidemiological surveillance.
\end{abstract}

\section{RESUMO}

Introdução: A infecção por Neisseria meningitidis, denominada doença meningocócica, pode causar meningite meningocócica e meningococcemia com ou sem meningite. A doença meningocócica é endêmica no Brasil; no entanto, o alto potencial de causar epidemias e letalidade elevada impõe a notificação imediata dos casos ao Sistema de Informação de Agravos de Notificação (SINAN) do Brasil. O objetivo deste estudo foi descrever o perfil epidemiológico, utilizando registros de casos notificados e confirmados no Estado de Minas Gerais, Brasil, de janeiro de 2000 a dezembro de 2009, obtidos a partir da ficha individual de investigação de meningites registrada no SINAN. Métodos: Trata-se de um estudo retrospectivo, de base populacional. Foram realizadas análises descritivas dos dados, a partir das frequências simples absolutas e relativas para as variáveis categóricas da ficha de investigação e teste qui-quadrado. Resultados: Houve 1.688 casos confirmados em Minas Gerais, dos quais 45,5\% residiam no centro, norte e Triângulo Mineiro. As maiores frequências foram nos pacientes do grupo etário de 1 a 4 anos (26,3\%), sexo masculino (54,7\%), brancos (36,4\%) e residiam em zona urbana (80\%). Dos casos com escolaridade especificada, $650(60,9 \%)$ casos cursaram ensino médio completo. Foram sorogrupados e classificados segundo idade e sexo $500(29,6 \%)$ casos, e desses 285 (57\%) foram sorogrupo C, $67(13,4 \%)$ da faixa etária de 1 a 4 anos e 168 (33,6\%) do sexo masculino. Conclusões: O perfil epidemiológico dos casos nas regiões centro e norte e Triângulo Mineiro não apresentaram diferenças importantes comparado ao perfil dos casos de Minas Gerais. Palavras-chaves: Meningite meningocócica. Epidemiologia. Vigilância epidemiológica.

1. Disciplina de Produção Técnico-Científica Interdisciplinar, Universidade Paulista, Campus Brasília, Brasília, DF. 2. Departamento de Medicina Social, Universidade Federal do Triângulo Mineiro, Uberaba, MG.

Address to: Profa. Sybelle de Souza Castro Miranzi. Dept ${ }^{\circ}$ de Medicina Social/UFTM. Av. Getúlio Guaritá 159/sala 324, Centro Educacional, Bairro Abadia, 38025-440 Uberaba, MG, Brasil.

Phone: $55343318-5924$

e-mail: sybelle@mednet.com.br; lmscatena@uol.com.br

Received in 25/04/2011

Accepted in 30/09/2011

\section{INTRODUCTION}

Meningococcal disease (MD) is an infectious, contagious bacterial disease caused by the Neisseria meningitides bacterium. MD affects humans and its clinical spectrum oscillates from a healthy carrier state to transitory bacteremia with spontaneous resolution to fulminant septicemia. $\mathrm{MD}$ represents a considerable national health problem, is subject to epidemiological surveillance, and is on the national list of notifiable diseases in accordance with Ordinance no. 104, January 25, 2011, which mandates immediate notification of any such cases due to the increased risk of epidemics and high mortality ${ }^{1-3}$.

For the epidemiological surveillance system, MD is classified, according to the clinical condition and results of laboratory examinations, as meningococcal meningitis and meningococcemia with or without meningitis ${ }^{4}$.

Some of the risk factors for MD are intimate contact with a patient with invasive disease, recent respiratory disease, and passive or active smoking, although the relationship between exposure and the risk of MD is not necessarily linear. The risk of MD increases with domestic overcrowding when there are previous viral infections or chronic diseases. The age group below 5 years is more vulnerable. Children younger than 1 year, adults older than 60 years, and individuals with chronic conditions or immunosuppressive diseases are more susceptible ${ }^{4-8}$.

The combination of environmental conditions, host, and microorganism, including the immunological susceptibility of the population, particular climate conditions, low socioeconomic status, and transmission of virulent strains are necessary, but not sufficient, to trigger an epidemic. Besides the existence of these aspects, an infectious cofactor is also necessary, such as acute infections of the upper respiratory tract that can compromise the mucosa and increase the probability of invasion by the meningococcus ${ }^{9,10}$. 
Serogroup B of N. meningitidis has been predominant since 1988 in Rio de Janeiro, followed by serogroup C. Since the 1990s, Brazil had a progressive increase in serogroup C outbreaks ${ }^{1,11-13}$.

Every suspicious case must be reported to the city health authorities who must immediately conduct epidemiological investigations and evaluate the need to adopt relevant control measures.

The Information System for Notifiable Diseases (SINAN) aims to collect and process notification data for diseases and disorders on the national list of mandatory notification diseases in Brazil, and permits states and municipalities to include other important health problems of their region on this list $t^{4,14,15}$.

Surveillance systems are necessary for the continuous documentation of the impact of a vaccine and changes in the epidemiology of diseases and to promote the sustainability of a vaccine. To reach a higher reduction in morbimortality, the maintenance of high infant immunization coverage must be achieved, particularly among more vulnerable populations ${ }^{16}$.

The Epidemiological Surveillance System for Meningitis, implemented in 1975 with the initial objective of controlling MD outbreaks in the country, comprises all of the activities and agents involved in the process from the identification of a suspicious case to the adoption of prevention measures and control of the disease within the community. The operation of the system presupposes good technical integration between the assistance given to the patients, the identification and study of the characteristics of the etiologic agent, and the epidemiological analysis of the disease's behavior within the population ${ }^{17}$.

In order to broaden the knowledge about the dynamics of MD in the State of Minas Gerais, we conducted a retrospective study to describe the epidemiological profile of the disease and the distribution of $N$. meningitidis serogroups in the $\mathrm{MD}$ cases according to their age group and gender in the State of MG and in 3 specific regions of the state, i.e., Central, North, and Triângulo Mineiro (TM), during 2000-2009.

\section{METHODS}

This was a retrospective, population-based study that focused on the epidemiology of MD in the State of MG and in 3 regions within the state, i.e., Central, North, and TM. The study period comprised 10 years, between January 2000 and December 2009.

The electronic database for confirmed notifications of MD was developed from the SINAN provided by the State of MG Department of Health (SES/MG). To describe the epidemiological profile of MD according to the variables of the individual research files according to year, age group, and gender, the following variables were used: age, gender, race/color, area of residence, education, vaccination, signs and symptoms, case classification, confirmation criteria, education, vaccination, $N$. meningitidis serogroup, chemoprophylaxis in contacts, and case evolution. Descriptive analyses of the data from the calculation of simple absolute and relative (percentage) frequencies for the categorical variables and chi-square test for proportions were performed. For the analysis of the data, we used Statistica 7.0 software from StatSoft.

The population data for age groups were necessary for the calculation of the coefficients and were provided by the Brazilian
Institute of Geography and Statistics and were obtained from the Technology Department of the Public Health Care System-SUS (DATASUS) for 2000-2009 ${ }^{17}$.

The variables used to define the population were population, reference year, place of residence, age group, and gender. Seven age groups were considered ( $<1$ year, 1-4 years, 5-9 years, 10-19 years, 20-39 years, $40-59$ years, and $>60$ years) for the calculation of the incidence rates, mortality, and lethality.

Cases confirmed by specific laboratory tests (i.e., culture, counterimmunoelectrophoresis (CIE), and latex fixation test) were included. In addition, we included (a) all suspected cases of meningitis with a history of an epidemiological link with a laboratory-confirmed case via one of the specified tests and (b) every suspected case with positive results for nonspecific laboratory tests such as bacterioscopy and cytochemistry and a compatible clinical evolution ${ }^{4}$.

First, we grouped the municipalities of residence and classified them according to health macro-regions. On the basis of the state divisions according to the Directive Regionalizing Plan, which divides the state into 13 macro-health regions, 4 regions of interest were selected: Central, North, Triângulo do Norte, and Triângulo do Sul; the last 2 regions are unified to form the TM region with a population equivalent to the North region of MG. The total population of all 3 regions, i.e., Central, North, and TM, forms approximately $50 \%$ of the overall population of the state $\mathrm{e}^{18,19}$.

To evaluate the proportional distribution of MD cases according to the serogroup of $N$. meningitidis by age group and gender, the number of MD cases by serogroup and the percentage distribution according to age group and gender were calculated using the simple absolute and relative frequencies.

\section{Ethical considerations}

Although the database provided by SES/MG did not have variables that identified the patients, the study was submitted for the approval of the Ethics Committee in Research involving Human Beings from the Universidade Federal do Triângulo Mineiro and approved under protocol no. 1646.

\section{RESULTS}

In the State of MG, from 18,434 notified suspected cases of MD and other meningitis cases during 2000-2009, 14,300 (77.6\%) cases were confirmed. From those cases, 1,690 (11.8\%) were cases specified as $\mathrm{MD}$, meningococcemia without meningococcal meningitis, and the 2 associated clinical forms constituting $\mathrm{MD}^{2}$.

The distribution of MD cases in MG revealed that 768 (45.5\%) lived in the Central, North, and TM regions. The Central region had the highest number of cases (540 cases; $32 \%$ ), followed by the TM region ( 153 cases; $9.1 \%$ ) and the North region (75 cases; $4.4 \%)$. Amongst the 1,690 specified cases, 1,688 were confirmed, $851(50.4 \%)$ were cases of meningococcal meningitis (MM), $443(26.2 \%)$ were cases of meningococcemia without meningococcal meningitis (MMC), and 394 (23.3\%) were cases of meningococcemia with meningococcal meningitis (MMC+MM). The chi-square test $(\mathrm{p}<0.0001)$ indicated a significantly higher proportion of MMC+MM in the Central (43.4\%) and North (6.6\%) regions and a higher prevalence of MM cases in the TM region (10.1\%) (Table 1). 
We observed a higher proportion of cases in the 1-4-years age group in MG and in the Central region with $434(26.3 \%)$ and $153(28.3 \%)$ cases, respectively. In the North and TM regions, the 10-19-years age group had the highest proportion of cases with $23(30.7 \%)$ and $34(22.2 \%)$ cases, respectively. There was a statistically significant difference between the proportions $(\mathrm{p}<0.0001)$. In MG, there was a predominance of male cases (924 cases; 54.7\%). In the 3 regions, i.e., Central, North, and TM, a similar gender bias was observed; however, there was a larger number of male cases in the North region. The chi-square test indicated that these proportions were significantly different $(\mathrm{p}=0.0150)$, for which the category ignored was disregarded from the analysis. In the majority of the cases in MG as well as in the Central and TM regions, the patients belonged tothe white population (615 cases, $36.4 \%$ ); however, in the North region, the brown skin color was predominant (33 cases; 44\%). In the Central region, there were 228 (42.2\%) patients with the category ignored color, and in the North, 18 (24\%) patients were not registered for this category ( $p<0.0001)$. A large portion of all the confirmed patients (650 cases; $38.5 \%$ ) had completed secondary education in MG, as was observed in the Central, North, and TM regions with 208 (38.5\%), 24 (32\%), 47 (30.7\%) cases, respectively $(\mathrm{p}<0.0001)$. There were no illiterate patients in $\mathrm{MG}$ and the 3 regions. The majority of patients resided in urban areas, with 1,351 (80\%) patients in MG and 487 (90.2\%), $46(61.3 \%)$, and $141(92.2 \%)$ patients in the Central, North, and TM regions, respectively $(\mathrm{p}<0.0001)$ (Table 2).

The clinical signs and symptoms more frequently observed in confirmed cases of $\mathrm{MD}$ were fever (92.2\%), vomiting $(78.7 \%)$, stiff neck $(64.9 \%)$, headache $(62.4 \%)$, and petechiae (57.4\%), while the least frequent were Kernig's sign $(21.2 \%)$, seizures (19.1\%), and coma (14.7\%). In addition to the signs and symptoms, there is a field on the investigation sheet where other specific symptoms are written; the most frequent symptoms were mental confusion, irritability, malaise, diarrhea, and somnolence. Among the patients $<1$ year of age ( 248 cases), an important and frequent symptom was a bulging fontanelle (34.7\%).

The diagnostic criteria used for the etiological confirmation of MD in MG were as follows: culture ( 522 cases; $30.9 \%$ ), latex agglutination (309 cases; $18.3 \%$ ), bacterioscopy (203 cases; $12 \%)$, CIE (46 cases; $2.7 \%$ ), cytochemistry (4 cases; $0.2 \%$ ), other laboratory techniques ( 2 cases; $0.1 \%$ ), and PCR ( 1 case; $0.1 \%$ ). The cases that did not have the etiology identified by
TABLE 1 - Distribution of meningococcal disease cases, according to clinical form and region, during 2000-2009.

\begin{tabular}{|c|c|c|c|c|c|c|c|c|}
\hline & \multicolumn{2}{|c|}{ MM } & \multicolumn{2}{|c|}{ MMC } & \multicolumn{2}{|c|}{$\mathbf{M M C}+\mathbf{M M}$} & \multicolumn{2}{|c|}{$\begin{array}{c}\text { Inconsistent } \\
\text { cases }\end{array}$} \\
\hline & $\mathbf{n}$ & $\%$ & $\mathbf{n}$ & $\%$ & $\mathbf{n}$ & $\%$ & $\mathbf{n}$ & $\%$ \\
\hline Central & 235 & 27.6 & 134 & 30.2 & 171 & $43.4^{*}$ & 0 & 0.0 \\
\hline North & 35 & 4.1 & 14 & 3.2 & 26 & $6.6^{*}$ & 1 & 50.0 \\
\hline TriânguloMineiro & 86 & $10.1^{*}$ & 41 & 9.3 & 26 & 6.6 & 0 & 0.0 \\
\hline Others & 495 & $58.2^{*}$ & 254 & 57.3 & 171 & 43.4 & 1 & 50.0 \\
\hline Total & 851 & 100.0 & 443 & 100.0 & 394 & 100.0 & 2 & 100.0 \\
\hline
\end{tabular}

MM: meningococcal meningitis; MMC: meningococcemia without meningococcal meningitis; MMC+MM: meningococcemia with meningococcal meningitis; Others: other regions of the State of Minas Gerais. ${ }^{*} \mathrm{p}<0.001$ for the chi-square test.

TABLE 2 - Demographic characteristics of confirmed cases with meningococcal disease by region, in the State of Minas Gerais, Brazil, from 2000-2009.

\begin{tabular}{|c|c|c|c|c|c|c|c|c|}
\hline \multirow[b]{3}{*}{ Demographic characteristics } & \multicolumn{8}{|c|}{ Region } \\
\hline & \multicolumn{2}{|c|}{ MG } & \multicolumn{2}{|c|}{ Central } & \multicolumn{2}{|c|}{ North } & \multicolumn{2}{|c|}{ TM } \\
\hline & $\mathbf{n}$ & $\%$ & $\mathbf{n}$ & $\%$ & $\mathbf{n}$ & $\%$ & $\mathbf{n}$ & $\%$ \\
\hline \multicolumn{9}{|l|}{ Age (years) } \\
\hline$<1$ & 248 & 15.0 & 98 & 18.1 & 11 & 14.7 & 20 & 13.1 \\
\hline $1-4$ & 434 & 26.3 & 153 & 28.3 & 15 & 20.0 & 31 & 20.3 \\
\hline $5-9$ & 294 & 17.8 & 92 & 17.0 & 9 & 12.0 & 16 & 10.5 \\
\hline $10-19$ & 295 & 17.8 & 77 & 14.3 & 23 & 30.7 & 34 & 22.2 \\
\hline $20-39$ & 232 & 14.0 & 66 & 12.2 & 11 & 14.7 & 33 & 21.6 \\
\hline $40-59$ & 106 & 6.4 & 26 & 4.8 & 5 & 6.7 & 10 & 6.5 \\
\hline$\geq 60$ & 44 & 2.7 & 11 & 2.0 & 0 & 0.0 & 9 & 5.9 \\
\hline blank & 35 & 2.1 & 17 & 3.1 & 1 & 1.3 & 0 & 0.0 \\
\hline \multicolumn{9}{|l|}{ Gender } \\
\hline male & 924 & 54.7 & 305 & 56.5 & 53 & 70.7 & 85 & 55.6 \\
\hline female & 761 & 45.1 & 235 & 43.5 & 22 & 29.3 & 67 & 43.8 \\
\hline ignored & 3 & 0.2 & 0 & 0.0 & 0 & 0.0 & 1 & 0.7 \\
\hline \multicolumn{9}{|l|}{ Skin color } \\
\hline white & 615 & 36.4 & 135 & 25.0 & 13 & 17.3 & 82 & 53.6 \\
\hline black & 98 & 5.8 & 22 & 4.1 & 4 & 5.3 & 11 & 7.2 \\
\hline yellow & 9 & 0.5 & 0 & 0.0 & 2 & 2.7 & 1 & 0.7 \\
\hline brown & 358 & 21.2 & 113 & 20.9 & 33 & 44.0 & 25 & 16.3 \\
\hline Indian & 1 & 0.1 & 0 & 0.0 & 0 & 0.0 & 0 & 0.0 \\
\hline ignored & 316 & 18.7 & 228 & 42.2 & 5 & 6.7 & 7 & 4.6 \\
\hline blank & 291 & 17.2 & 42 & 7.8 & 18 & 24.0 & 27 & 17.6 \\
\hline \multicolumn{9}{|l|}{ Education } \\
\hline illiterate & 0 & 0.0 & 0 & 0.0 & 0 & 0.0 & 0 & 0.0 \\
\hline$<4$ years of elementary school & 147 & 2.8 & 12 & 2.2 & 1 & 1.3 & 6 & 3.9 \\
\hline $4^{\text {th }}$ year of elementary school & 74 & 4.4 & 24 & 4.4 & 8 & 10.7 & 4 & 2.6 \\
\hline$<8$ years of elementary school & 185 & 11.0 & 38 & 7.0 & 9 & 12.0 & 26 & 17.0 \\
\hline complete elementary school & 68 & 4.0 & 11 & 2.0 & 7 & 9.3 & 7 & 4.6 \\
\hline$<3$ years of high school & 34 & 2.0 & 4 & 0.7 & 1 & 1.3 & 4 & 2.6 \\
\hline high school & 650 & 38.5 & 208 & 38.5 & 24 & 32.0 & 47 & 30.7 \\
\hline incomplete higher school & 3 & 0.2 & 0 & 0.0 & 0 & 0.0 & 3 & 2.0 \\
\hline higher school & 6 & 0.4 & 3 & 0.6 & 0 & 0.0 & 1 & 0.7 \\
\hline ignored & 275 & 16.3 & 119 & 22.0 & 6 & 8.0 & 27 & 17.6 \\
\hline not applied & 212 & 12.6 & 86 & 15.9 & 7 & 9.3 & 15 & 9.8 \\
\hline blank & 134 & 7.9 & 35 & 6.5 & 12 & 16.0 & 13 & 8.5 \\
\hline \multicolumn{9}{|l|}{ Area of residence } \\
\hline urban & 1,351 & 80.0 & 487 & 90.2 & 46 & 61.3 & 141 & 92.2 \\
\hline rural & 209 & 12.4 & 20 & 3.7 & 26 & 34.7 & 4 & 2.6 \\
\hline peri-urban & 14 & 0.8 & 7 & 1.3 & 1 & 1.3 & 0 & 0.0 \\
\hline ignored & 21 & 1.2 & 9 & 1.7 & 1 & 1.3 & 0 & 0.0 \\
\hline blank & 93 & 5.5 & 17 & 3.1 & 1 & 1.3 & 8 & 5.2 \\
\hline Total cases & 1,688 & & 540 & & 75 & & 153 & \\
\hline
\end{tabular}

MG: Minas Gerais; TM: Triângulo Mineiro. 
laboratory criteria, but had a diagnosis of MD confirmed by clinical criteria and clinical-epidemiological data, were 495 (29.3\%) and 13 $(0.8 \%)$ cases, respectively. The remaining cases were confirmed using an epidemiological link (22 cases; $1.3 \%)$, necropsy ( 5 cases; $0.3 \%)$, death certificate ( 2 cases; $0.1 \%$ ), and other criteria ( 29 cases; $2.3 \%$ ). Of the 1,688 cases of $\mathrm{MD}$, only 18 (1.1\%) did not have specific diagnostic criteria and $9(0.5 \%)$ had incorrect data.

Of all cases of MD, 945 (56\%) had 7,497 contacts with other people. The Central region had the highest number of contacts (279 contact; $29.5 \%)$, followed by the TM (93 contacts; $9.8 \%)$ and North (47 contacts; $5 \%$ ) regions. Chemoprophylaxis was performed in the contacts of 1,164 (68.9\%) confirmed cases in MG, while the contacts of $166(9.9 \%)$ cases did not receive chemoprophylaxis. The highest frequency of chemoprophylaxis occurred in the contacts of the Central region cases with 451 (38.7\%) contacts, followed by those in the TM (97 contacts; $8.3 \%$ ) and North (48 contacts; $4.1 \%)$ regions.

Regarding the evolution of the confirmed cases of MD in the State of MG, there were 1,161 (68.8\%) hospital discharges and $452(26.8 \%)$ deaths by meningitis.

In the 3 regions, the highest incidence was among children aged $<1$ year, followed by the 1-4- and 5-9-years age groups. In the Central region, among children aged $<1$ year, there was an incidence between 5.70-14.02 cases/100,000 inhabitants per year, while 2.34-5.29 cases/100,000 inhabitants per year were observed in the 1-4-years age group. In the TM region, among children aged $<1$ year, there was an incidence between 3.67-26.79 cases/100,000 inhabitants per year, while $0.89-5.10$ cases/100,000 inhabitants per year were observed in the 1-4-years age group. In the North region, among children aged $<1$ year there was an incidence between 3.2113.14 cases $/ 100,000$ inhabitants per year, while between 1.56-5.00 cases $/ 100,000$ inhabitants per year were observed in the 1-4-years age group. In MG and in the Central, North, and TM regions, the largest mortality coefficients were observed in children aged $<1$ year, followed by the 1-4-years age group. The highest mortality rate in the state reached 4.08 deaths $/ 100,000$ inhabitants per year in children aged $<1$ year in 2001 . For the same year and age group, the mortality rate in the TM region was 11.48 deaths $/ 100,000$ inhabitants per year.
The highest lethality of MD in MG (35.2\%) occurred in 2006. The highest lethality observed in the Central and TM regions occurred in 2005 (41.3\% and $45.5 \%$, respectively), with the highest (57.1\%) lethality in the North region observed in 2001. From 20002009 in MG, the highest lethality of MD occurred in adults aged $>60$ years, followed by children aged $<1$ year and those aged 1-4 years. In the Central region, high lethality was observed for those aged $<19$ years. In the North region, the lethality was very high (100\%) among various age groups. In the TM region, in children aged $<1$ year and between 1-4 years, the lethality was high until 2003 and declined after 2006.

The predominant clinical form of MD was MM, which was observed in $50.4 \%$ of cases in MG and in $43.5 \%$ of cases in the Central region, $56.2 \%$ in the TM region, and $46.7 \%$ in the North region. The highest frequency of cases of MM occurred in the 1-4-years age group in $\mathrm{MG}$ (27.1\%). The average incidence of $\mathrm{MM}$ was 0.44 cases $/ 100,000$ inhabitants per year and the average mortality of MM was $0.64 \%$ deaths $/ 100,000$ inhabitants per year.

During 2000-2009 in MG, serogrouping of N. meningitidis was conducted in 511 (30.3\%) confirmed MD cases. Of those, there were $500(29.6 \%)$ cases with information about age group and gender. Serogroup C was the most frequent with 285 (57\%) cases, of which 168 (58.9\%) cases were male, followed by serogroup B with $189(37.8 \%)$ cases, of which $106(56.1 \%)$ cases were male. The highest frequency of serogroup $\mathrm{C}$ was observed in female children aged from $1-4$ years ( 35 cases; $29.9 \%$ ), while the highest frequency of serogroup B was observed in male children aged $<1$ year $(31$ cases; $29.2 \%$ ). The least frequent serogroups were $\mathrm{Y}, \mathrm{A}$, and W135 (Table 3).

Serogroup C was more frequent in the Central region with $112(58.6 \%)$ cases, of which $58 \%$ of cases were male, while in the TM region, 25 (65.8\%) cases were detected, of which 68\% were male. In the North region, serogroup B was more (50\%) frequent with a high $(80 \%)$ prevalence in females. In the Central region, serogroup A was the least frequent. In the TM region, there were no cases of serogroups A, Y, and W135. In the North region, there was no occurrence of serogroup A.

TABLE 3 - Distribution of Neisseria meningitidis serogroups, by age and gender, in the State of Minas Gerais, Brazil, during 2000-2009.

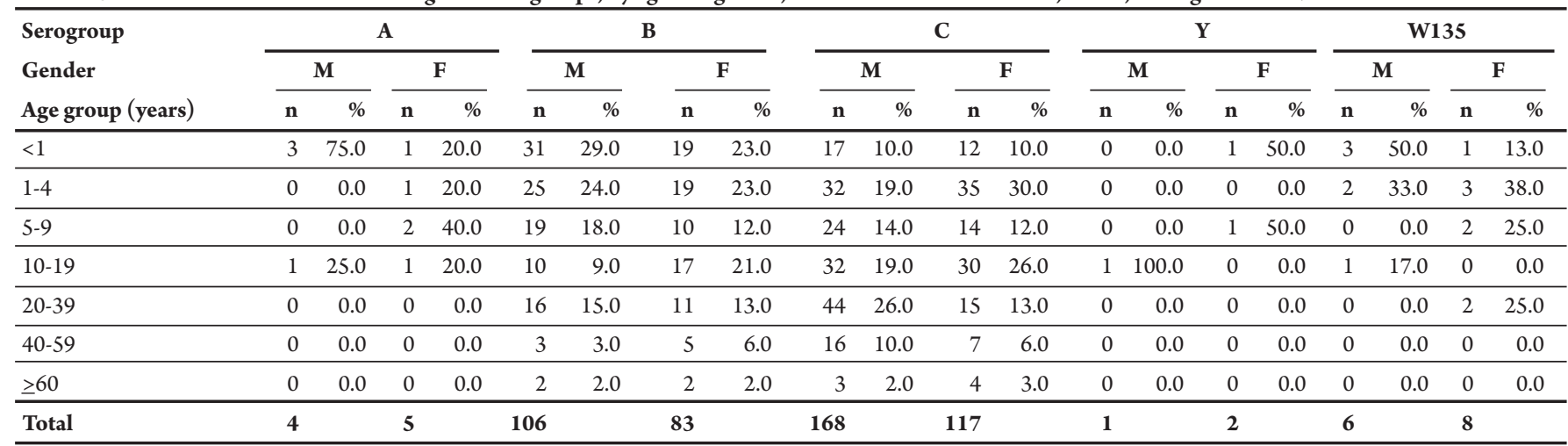

A, B, C, Y, and W135: serogroups; M: male; F: female. 


\section{DIscussion}

In the State of MG, from 2000-2009, there were $~ 168.8$ annual cases of MD with an average incidence of 0.88 cases $/ 100,000$ inhabitants per year and an average annual lethality of $25.8 \%$, resulting in an average of 45.2 deaths/year. The incidence of MD in the state from $2000-2009$ had a variation of $0.46-1.22$ cases $/ 100,000$ inhabitants per year, lower than the average in Brazil (1.22-2.47 cases/100,000 inhabitants per year) during the same period. The mortality coefficient was also lower than the average MD mortality in the country, with a variation from 0.07-0.38 deaths/100,000 inhabitants per year in MG compared with a variation of 0.25-0.45 deaths/100,000 inhabitants per year in $\mathrm{Brazil}^{20}$.

Meningococcal Disease remains endemic in MG. It was observed that the annual average of 168.8 cases during 2000-2009 found in this study was higher than the annual average of $\sim 133.9$ cases of bacterial meningitis due to $N$. meningitidis, which corresponds to an average percentage of $15 \%$ of the total number of bacterial meningitis cases (47\% of 1,900 cases of meningitis) in MG during 1990-2006. During this period, the incidence rate per 100,000 inhabitants varied for MD from 2.97 cases in 1995 to 0.81 in 2006, without the characterization of outbreaks ${ }^{21}$.

In 2000, the SINAN was decentralized to the municipalities, leading to possible underreporting of cases of meningitis due to difficulties in the transfer of typed data to the regional health management centers. ${ }^{21}$

These data suggest that the underreporting of meningitis cases due to the lack of a standardized system and the consolidation of information resulting from the decentralization of the system with the transfer of data entry to the Regional Health Management and, later, to almost all municipalities in the state, added to the constant turnover of epidemiological surveillance technicians ${ }^{22-24}$.

Considering the absolute frequency of the cases, the highest ratio was observed in males of the 1-4-years age group in MG, which agrees with the findings of other studies ${ }^{24-26}$. Possible explanations for the high proportion of male cases are the facts that men have a tendency of taking less care of their health, expose themselves to a higher amount of risky situations, and seek the help of health care services less often than women. There are several factors contributing to these explanations, including work-related matters, the fear of discovering a serious disease, and the view that women are typically more concerned about health-related issues. This leads to men becoming more vulnerable to MG, and when they finally seek medical attention, the disease is frequently at an advanced stage ${ }^{27}$.

The epidemiological profile of the cases in each region did not present important differences compared to the profile of the state. In the North region, there was a higher occurrence of cases among people of the brown skin color. In MG and the Central and TM regions, the white color was predominant, which contradicts the findings of a study conducted in the United States in 1993 where the incidence was higher among African Americans ( 1.5 cases per 100,000 inhabitants) than in Caucasians ( 1.1 cases per 100,000 inhabitants $)^{28}$.

Regarding the educational level, there were no cases with illiteracy in MG and in the Central, TM, and North regions. The highest number of cases was among patients who had completed secondary education (38.5\%), presumably, then, that despite the epidemic character and lethality of MD, this population should have more access to information about MD and the dynamics of its transmission. However, there are no prevention measures originating from government health policies that address the prevention of MM among adolescents and adults. Patients who had completed their secondary education were also predominant in the state as well as in the 3 regions due to the higher availability of access to education in these areas.

Only $3.8 \%$ of the confirmed cases of MD in TM lived in a rural area, lower than the $12.4 \%$ of cases living in rural areas in the state. However, it is crucial to maintain a constant vigilance in rural areas, investigating cases and contacts. Despite noting a higher frequency of cases in the urban areas of MG and the Central and TM regions, there is a need to implement strategies with an emphasis on the rural areas in the North region because $34.7 \%$ of the cases lived in these rural areas.

The most frequent signs and clinical symptoms were similar to those described by Stella-Silva, Oliveira, and Marzochi ${ }^{30}$ in a study conducted in Rio de Janeiro from 1971-1996.

In the state, during 2000-2009, serogrouping of the etiologic agent $N$. meningitidis was achieved in 511 (30.3\%) confirmed cases, and these data are similar to the percentage of serogrouping achieved during 1990-2006 in MG (25-30\%), there by confirming the precariousness of the laboratory diagnosis of $\mathrm{MD}$ and the unreliable evaluation of the serotypes and subtypes circulating in $\mathrm{MG}^{21}$.

Botelho et al. ${ }^{21}$ identified the predominance of serogroup $\mathrm{C}$ in cases of MD during 1990-2006. Serogroup C was responsible for $57 \%$ of the cases from 2000-2009 in MG. The only period when the highest number of cases was from serogroup B was from 2001-2002, when serogroup C was predominant (as also observed in 2004). In 2009, there were 73 (75.3\%) cases of MD with serogroup C. However, the same behavior was not observed in a study of the epidemiological profile of acute bacterial meningitis in the State of Rio Grande do Norte, from 2005-2008, in which there were 11 (61.1\%) cases of $\mathrm{MD}$ with serogroup $\mathrm{B}^{31}$.

There were an excessive number of cases, 405 (29.3\%), that did not have the etiology identified using laboratory criteria, but had their diagnosis of MD considered confirmed by clinical criteria. The elevated percentage of cases with non-specified etiology reflects problems in the care process, i.e., in collecting, transporting, and/ or processing of cerebrospinal fluid samples, which corroborates the findings of other studies ${ }^{25,32}$.

Highly specific diagnostic criteria, e.g., culture, latex agglutination, and CIE, were generated in $51.9 \%$ of the confirmed cases during 2000-2009, which was $2.9 \%$ more than that in the study performed by Botelho et al. ${ }^{21}$ in MG during 1990-2006. However, it still indicates that although there was an improvement in the quality of laboratory diagnosis, there are still many cases without a specific diagnosis and identification of the serogroup, making it difficult to use serogroupspecific vaccines during routine vaccinations.

The alleged under-notification of MD cases due to the lack of identification of the etiologic agent and the low percentage of confirmed bacterial meningitis cases using culture and laboratory criteria show that there are flaws in the epidemiologic surveillance program in MG because these are operational indicators of the quality of surveillance. Due to possible unconfirmed cases of MD, chemoprophylaxis as a control measure was not conducted in all of the intimate contacts of the cases. However, this is an essential measure to prevent secondary cases, considering that the etiologies for which the chemoprophylaxis is administered are meningococcal disease and Haemophilus influenzae meningitis?. 
According to Botelho et al. ${ }^{21}$, the precariousness of laboratory diagnosis may be due to the lack of qualified laboratories to perform specific tests in municipalities; territorial distance, which makes it difficult to send samples to other laboratories and to the Ezequiel Dias Foundation; inadequate amount of skilled technicians for municipal surveillance; high rotation of technicians; and lack of awareness in health care professionals about the priority of laboratory tests for etiologic diagnosis.

It is concluded that the quality of assistance given to patients with MD is directly related to the resolvability and effectiveness of the activities performed by the epidemiological surveillance system, e.g., accurate investigation of the cases, collection and processing of data, analysis and interpretation of the processed data, feeding and maintaining information systems, epidemiological investigations of cases and outbreaks, active search for secondary cases, analysis of the results obtained from surveillance, and recommendations and the promotion of control measures given in a timely manner.

Besides considering the quality of the information in the investigation files that contribute to the description of the epidemiological situation of the disease in the population studied, the organizational structure, amount of available human resources, technical expertise, and working conditions of the professionals that perform surveillance at the local and regional levels in the State of MG should be considered.

\section{ACKNOWLEDGMENTS}

We thank the Department of Health of the State of Minas Gerais for providing access to the database.

\section{CONFLICT OF INTEREST}

The authors declare that there is no conflict of interest.

\section{REFERENCES}

1. Pacheco LMM, Pereira LAA, Silva ZP, Teixeira MCB, Lopes AC. Doença meningocócica: aspectos epidemiológicos, fatores de risco e prevenção. Rev Soc Bras Clin Med 2007; 5:87-91.

2. Ministério da Saúde. Secretaria de Estado da Saúde de São Paulo, Coordenadoria de Controle de Doenças. Informe Técnico Institucional. Investigação de surto comunitário de doença meningocócica no Município de São Paulo. Rev Saude Publica 2007; 41:873-878.

3. Portaria $\mathrm{n}^{\circ} 104$, de 25 de janeiro de 2011. Define as terminologias adotadas em legislação nacional, conforme o disposto no Regulamento Sanitário Internacional 2005 (RSI 2005), a relação de doenças, agravos e eventos em saúde pública de notificação compulsória em todo o território nacional e estabelecefluxo, critérios, responsabilidades e atribuições aos profissionais e serviços de saúde. Fica revogada a Portaria GM/ MD no 2.472/10. Diário Oficial da União, Brasília, 2011. Seção1, p. 37-38.

4. Ministério da Saúde. Departamento de Vigilância Epidemiológica. Secretaria de Vigilância em Saúde, Caderno 12. Meningites. Guia de Vigilância Epidemiológica. 7a ed. Brasília: Ministério da Saúde; 2009. p. 21-47.

5. Farhat CK, Marques SR. Doenças Meningocócicas. In: Farhat CK, Carvalho LHRF, Succi RCM, editors. Infectologia Pediátrica. São Paulo: Editora Atheneu; 2007. p. 413-429.

6. Maclennan J, Kafatos G, Neal K, Andrews N, Cameron JC, Roberts R, et al. Social behavior and meningococcal carriage in British teenagers. Emerg Infect Dis 2006; 12:950-957.

7. Coen PG, Tully J, Stuart JM, Ashby D, Viner RM, Booy R. Is it exposure to cigarette smoke or to smokers which increases the risk of meningococcal disease in teenagers? Int J Epidemiol 2006; 35:330-336.

8. Centers for disease control and prevention. Prevention and control of meningococcal disease: recommendations of the Advisory Committee on Immunization Practices (ACIP). Morb Mortal Wkly Rep 2005; 54 (RR-7):1-21.

9. Schwartz B, Moore PS, Broome CV. Global epidemiology of meningococcal disease. Clin Microbiol Rev 1989; 2:118-124.
10. World Health Organization. WHO practical guidelines. Control of epidemic meningococcal diseases. $2^{\text {nd }}$ ed. Genebra: WHO; 1998.

11. Ministério da Saúde/Secretaria de Vigilância em Saúde. Guia de vigilância epidemiológica. $6^{\text {th }}$ ed. Brasília: Ministério da Saúde; 2005.

12. Ministério da Saúde, Secretaria de Vigilância em Saúde, Departamento de Vigilância Epidemiológica. Nota técnica - Doença Meningocócica por sorogrupo C no município de Búzios, RJ. Brasília: Ministério da Saúde; 2008. [cited 2010 March 5]. Available from: http://portal.saude.gov.br/portal/arquivos/pdf/ buzios_180108.pdf/.

13. Gabastou JM, Agudelo CI, Brandileone MCC, Castañeda E, Lemos APS Di Fabio JL, et al. Caracterización de aislamientos invasivos de S. pneumoniae, H. influenzae y N. meningitidis en América Latina y El Caribe: SIREVA II, 2000-2005. Rev Panam Salud Publica 2008; 24: 1-15.

14. Ministério da Saúde. Secretaria de Vigilância em Saúde, Departamento de Vigilância Epidemiológica, Coordenação Geral de Doenças Transmissíveis, Coordenação de Vigilância das Doenças de Transmissão Respiratórias e Imunopreveníveis. Nota Técnica Meningocócica no Brasil. Brasília: Ministério da Saúde; 2010.

15. LaguardiaJ,Domingues CMA, Carvalho C,Lauerman CR, MacárioE, GlattR. Sistema de Informação de Agravos de Notificação (SINAN): desafios no desenvolvimento de um sistema de Informação em saúde. Epidemiol Serv Saude 2004; 13:135-147.

16. World Health Organization. Departamento de Imunização, Vacinas e Produtos Biológicos. Global immunization coverage in 2008. Genebra: WHO; 2009. [cited 2009 Oct 21] Available from: http://www.who.int/immunization/newsroom/ GID_english.pdf/.

17. Ministério da Saúde. Departamento de Informática do Sistema Único de Saúde [Internet]. Brasília: Ministério da Saúde; 2009. Available from: http://www. datasus.gov.br/.

18. Ministério da Saúde. Secretaria de Estado da Saúde de Minas Gerais, Superintendência de Regulação, Gerência de Regulação Assistencial. Sistema Estadual de Regulação Assistencial de Minas Gerais. $1^{\mathrm{a}}$ ed. Belo Horizonte: SES/MG; 2006.

19. Instituto Brasileiro de Geografia e Estatística. Estimativa das Populações dos Municípios em 2009. Brasília: Ministério do Planejamento, Orçamento e Gestão. IBGE; 2009.

20. Ministério da Saúde. Sistema de Informação de Agravos de Notificação (SinanNET) [Internet]. Brasília: Ministério da Saúde; 2010. Available from: http://dtr2004.saude.gov.br/sinanweb/

21. Botelho PP, Côrtes MCJW, Diniz SMN, Rodrigues GJC. Situação epidemiológica das meningites em Minas Gerais, 1990-2006: incidência, etiologia, letalidade e critério diagnóstico. Rev Med Minas Gerais 2007; 17:S249-S257.

22. Ministério da Saúde, Secretaria de Vigilância em Saúde, Departamento de Vigilância Epidemiológica. Programa Nacional de Imunizações. Manual dos Centros de Referência para Imunobiológicos Especiais. Brasília: Ministério da Saúde; 2006.

23. Miranzi SSC, Moraes SA, Freitas ICM. Tendência das meningites por Haemophilus influenzae tipo b no Brasil, em menores de 5 anos, no período de 1983 a 2002. Rev Soc Bras Med Trop 2006; 39:473-477.

24. Mantese OC, Hirano J, Santos IC, Silva VM, Castro E. Perfil etiológico das meningites bacterianas em crianças. J Pediatr 2002; 78:467-474.

25. Weiss DPL, Coplan P, Guess H. Epidemiology of bacterial meningitis among children in Brazil, 1997-1998. Rev Saude Publica 2001; 35:249-255.

26. Santos ML, Ruffino-Netto A. Doença meningocócica: situação epidemiológica no Município de Manaus, Amazonas, Brasil, 1998/2002. Cad Saude Publica 2005 ; 21:823-829.

27. Gomes R, Nascimento EF, Araújo FC. Por que os homens buscam menos os serviços de saúde do que as mulheres? As explicações de homens com baixa escolaridade e homens com ensino superior. Cad Saude Publica 2007; 23:565-574

28. Jackson LA, Wenger JD. Laboratory-based surveillance for meningococcal disease in selected areas, United States, 1989-1991. In: CDC Surveillance Summaries. MMWR 1993; 42:21-30.

29. Instituto de Pesquisa Econômica Aplicada, Secretaria de Planejamento e Investimentos Estratégicos. Objetivos de Desenvolvimento do Milênio: relatório nacional de acompanhamento. Supervisão: Grupo Técnico para o Acompanhamento dos ODM. Brasília: IPEA; 2007.

30. Stella-Silva N, Oliveira SA, Marzochi KBF. Doença meningocócica: comparação entre formas clínicas. Rev Soc Bras Med Trop 2007; 40:304-310.

31. Silva WA, Pinheiro AM, Coutinho LG, Marinho LAC, Lima LFA. Perfi epidemiológico da meningite bacteriana aguda no Estado do Rio Grande do Norte, Brasil. Rev Soc Bras Med Trop 2010; 43:455-457.

32. Escosteguy CC, Medronho RA, Madruga R, Dias HG, Braga RC, Azevedo OP. Vigilância epidemiológica e avaliação da assistência às meningites. Rev Saude Publica 2004; 38:657-663. 